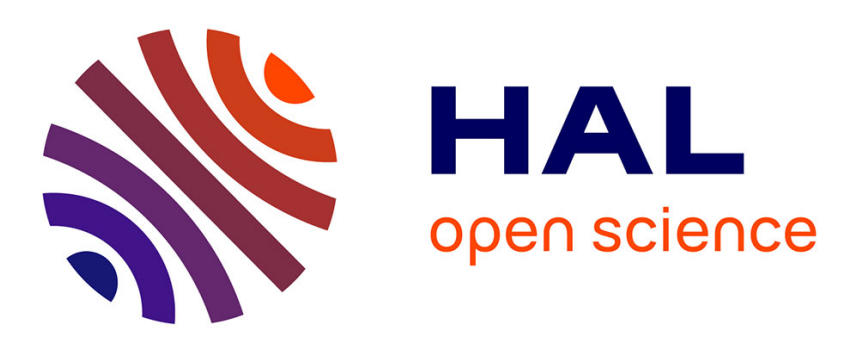

\title{
Wavefront synthesis in a reverberation chamber: First experimental results
}

\author{
Andrea Cozza, Florian Monsef
}

\section{To cite this version:}

Andrea Cozza, Florian Monsef. Wavefront synthesis in a reverberation chamber: First experimental results. 5èmes Journées Electromagnétisme et Guerre Electronique, Dec 2015, Toulouse, France. 2015, 10.1109/URSI-AT-RASC.2015.7303044 . hal-01241332

\section{HAL Id: hal-01241332}

https://hal-centralesupelec.archives-ouvertes.fr/hal-01241332

Submitted on 10 Dec 2015

HAL is a multi-disciplinary open access archive for the deposit and dissemination of scientific research documents, whether they are published or not. The documents may come from teaching and research institutions in France or abroad, or from public or private research centers.
L'archive ouverte pluridisciplinaire HAL, est destinée au dépôt et à la diffusion de documents scientifiques de niveau recherche, publiés ou non, émanant des établissements d'enseignement et de recherche français ou étrangers, des laboratoires publics ou privés. 


\title{
Wavefront Synthesis in a Reverberation Chamber: Experimental Results
}

\author{
Andrea Cozza, Florian Monsef \\ Pôle Physique et Ingénierie de l'Electromagnétisme \\ GeePs (UMR 8507), Université Paris Saclay
}

The TREC recipe in a nutshell: a) a weakly lossy diffusive environment (e.g., a reverberation chamber), b) a single source, with no special features and c) a scanning system for sampling Green's functions over a surface.
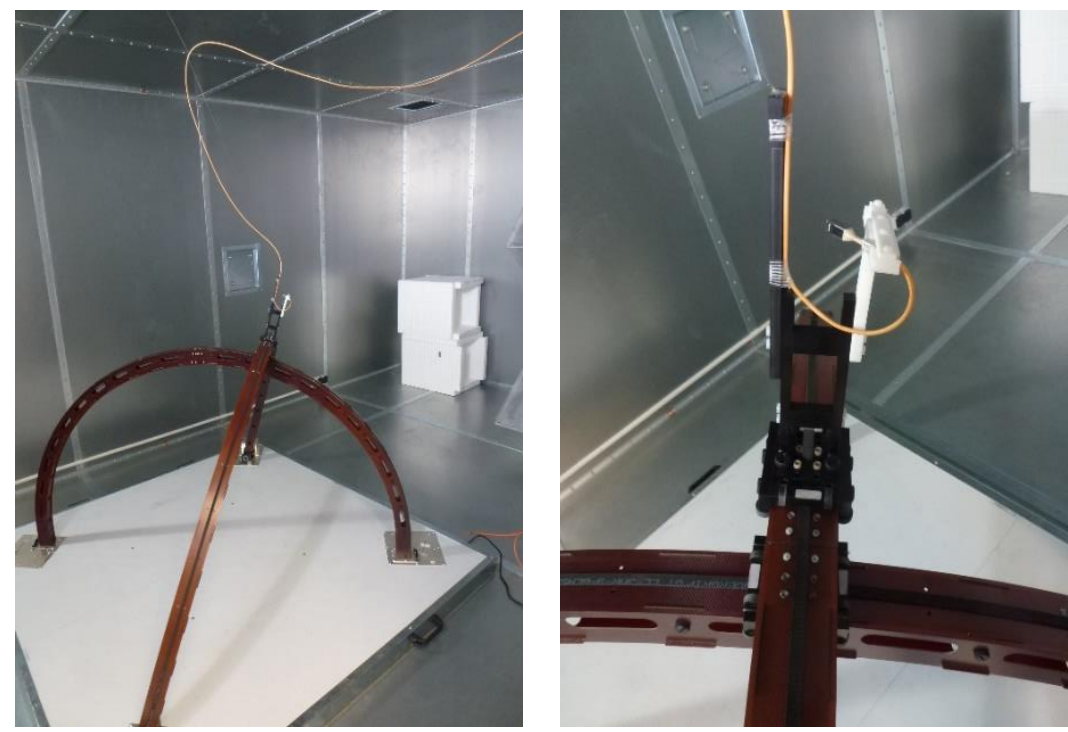

Fig. 1 : The robot optimized to weakly perturbate a reverberation chamber in the $\mathrm{GHz}$ range. On the right, a detail showing the electro-optic probe.

First automated validation. Goals: a) to assess how strongly the generated wavefronts contrast with the diffusive background, b) they reproductibility and c) their ability to generate spatially resolved EM stress.
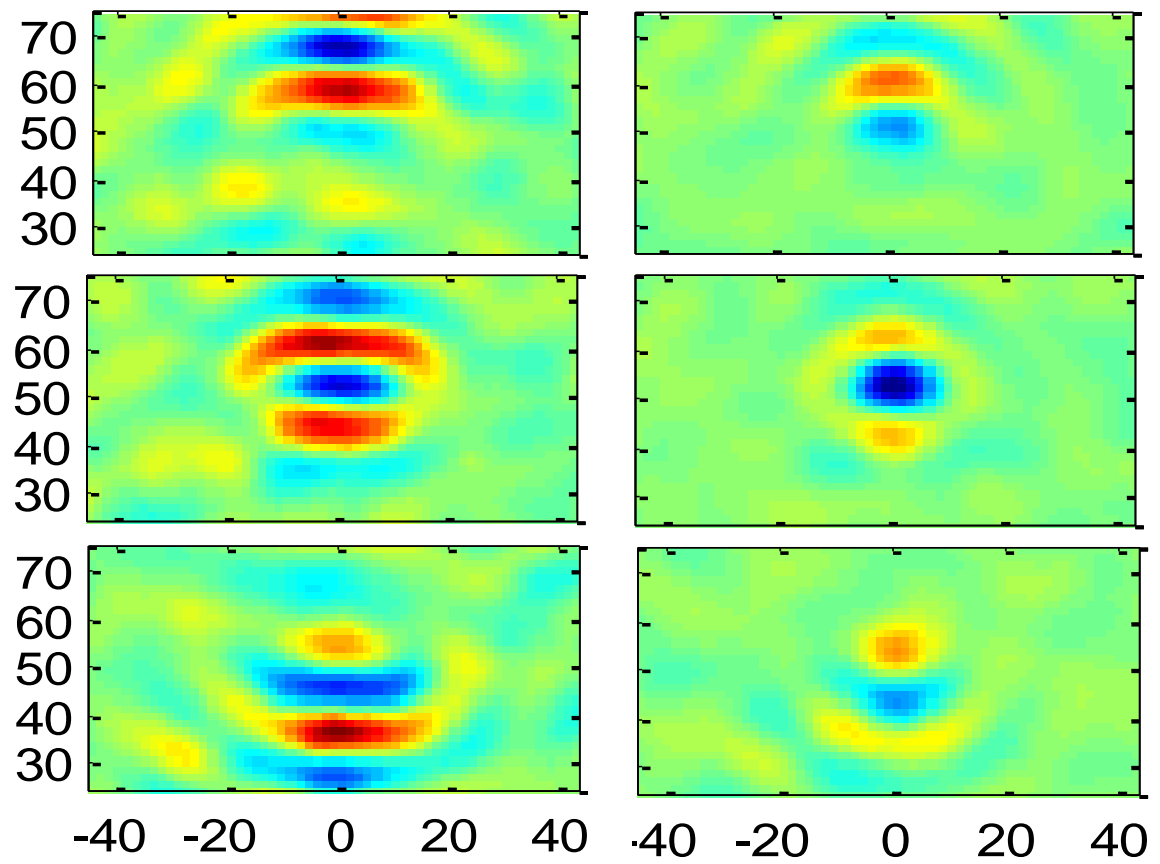

Fig. 2 : Wavefronts sampled at three time instants over a vertical plane, as they approach and leave the focal region (top to bottom): an example of local planar excitation (left column) and one limited by diffraction.
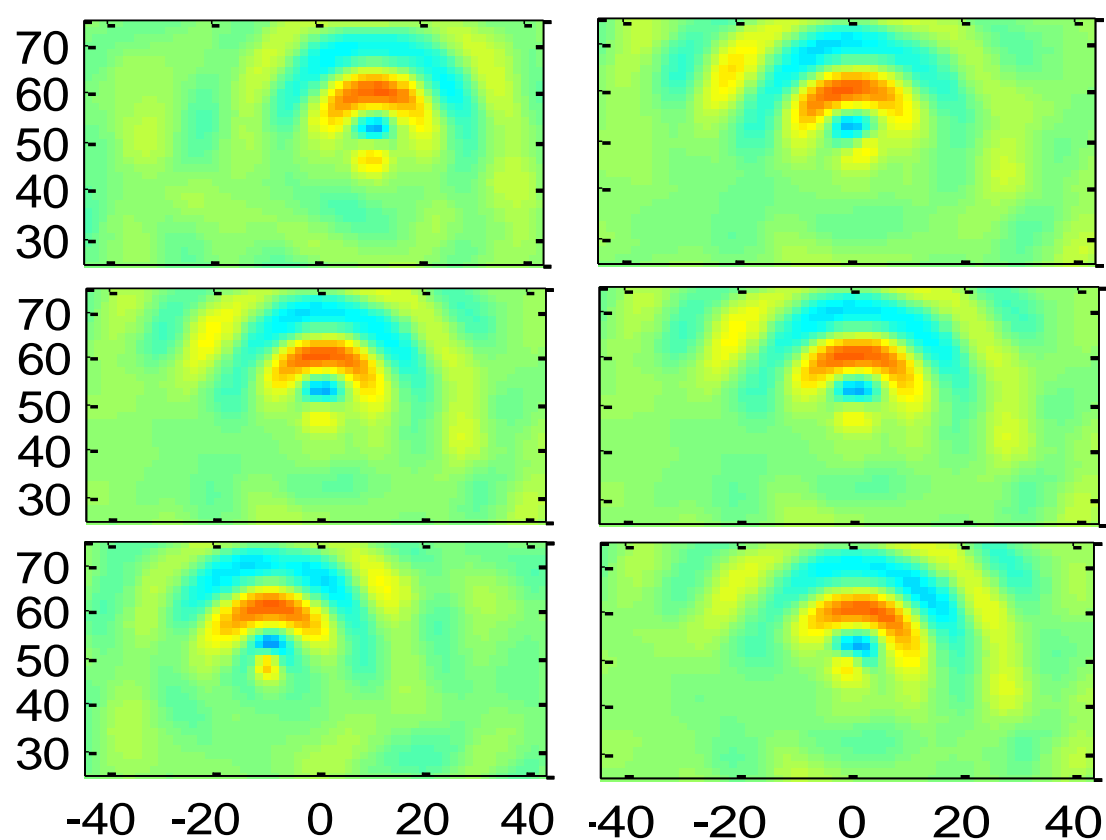

Fig. 3 : Testing the wavefront repeatability after translation (left column) and rotation (right column).

Observations: a) stable wavefronts against translation and rotation, b) good level of contrast (> $20 \mathrm{~dB})$, c) good polarization control.

Applications : a promising application currently developed is imaging coupling paths in metallic shields. An example is shown below.
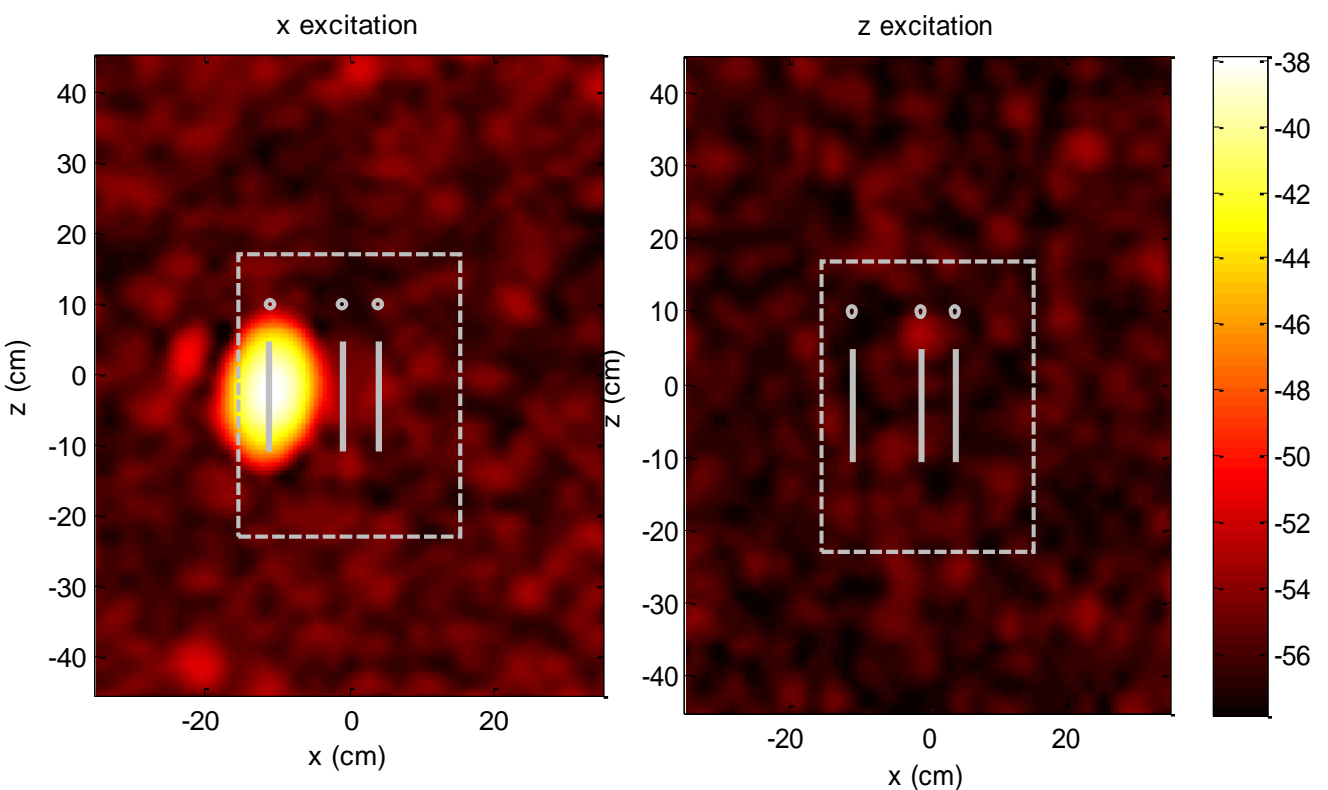

Fig. 4 : A transmission image of a slotted metal box, showing the position of a slot and its sensitivity to polarization. Moving focal spots were used in order to generate it.

\section{References}

[1] A. Cozza, Physical Review E 80, 5 (2009)

[2] A. Cozza, H. Moussa, IET Electronics Letters 45, 25 (2009)

[3] A. Cozza, IET Electronics Letters 46, 9 (2010)

[4] A. Cozza, H. Moussa, WO 2010/112763, (2010)

[5] A. Cozza, IEEE Transactions on Antennas and Propagation 60, 8 (2012)

[6] P. Meton et al, EuCAP, Goteborg (2013) 